\title{
The Arctic: Past the Last Frontier
}

\section{Christopher Kulander ${ }^{1}$ and Sergei Lomako ${ }^{2}$}

\begin{abstract}
L'exploration de l'océan Arctique et son utilisation pour le transport sont en pleine expansion, ainsi que les désaccords concernant les droits des pays périphériques - le Canada, la Finlande, le Danemark (Groenland), la Russie, et les États Unis. Ces pays affirment leurs propres prétentions de souveraineté, tout en contestant celles des autres au travers de négociations bilatérales ou de tribunaux internationaux. Malgré ses tentatives de tracés de frontières et de médiations, ces différends et ces traités bilatéraux soulèvent la question de savoir si les Nations Unies ont, à ce jour, offert un régime juridique international qui puisse satisfaire pleinement les états Arctiques. En attendant, les pays concernés poursuivent des programmes scientifiques et de développement de plus en plus complexes et ambitieux dans l'Arctique.
\end{abstract}

The use of the Arctic Ocean for exploration and transportation is increasing, as is disagreement regarding the rights of nations encircling it - Canada, Finland, Denmark (Greenland), Russia, and the United States. These nations are both making their own sovereign claims and contesting the claims of others through bilateral negotiations and use of international tribunals. Despite its attempts to define boundaries and mediate disputes, these disputes and bilateral treaties raise questions about whether the United Nations has yet provided an international legal regime entirely satisfying to the Arctic states. Meanwhile, countries in the region pursue increasingly complex and ambitious scientific and development agendas in the Arctic.

\section{Introduction}

With the Antarctic closed for exploitation, the Arctic represents the last frontier on earth for exploration and transportation. Previously, the North Pole's combination of frigid temperatures, icecap and abyssal ocean had precluded the region from much navigation and development. Now, with the search for oil and gas expanding into deeper

1 Christopher S. Kulander is an associate in the Energy \& Power Practice Group, Haynes and Boone, LLP, Houston, Texas.

2 Sergei Lomako is a partner in the Corporate Section, Haynes and Boone, LLC.

The Northern Mariner/le marin du nord, XX No. 1, (January 2010), 71-83 
waters and the potential opening of seasonal shipping lanes across polar routes, the nations that encircle the Arctic are jostling for optimum economic position. Countries with access to the north are consolidating icebreaker fleets, conducting scientific surveys, leasing acreage for oil and gas exploration into the Arctic Ocean, and making sovereign claims.

The term "Arctic" has different definitions. In geographic terms, the Arctic is the part of the Earth's surface north of $66.56756^{\circ}$ Northern latitude. Its primary feature is the Arctic Ocean, which stands with the Pacific, Atlantic, Southern (Antarctic), and Indian Oceans as a separate and discrete oceanic unit and covers about fourteen million square kilometers - comparable to the area of Russia. In political terms, countries with sovereign territories that extend into the Arctic continental shelf include Canada, Finland, Denmark (Greenland), Russia, and the USA - the "Arctic States" - as well as nonsovereign, international waters.

Certain parts of the Arctic region are located within the reach of national sovereign rights and claims. Other portions are considered by international law to be "high seas" and beyond any national jurisdiction. Before World War II, Russia claimed portions of the Arctic based on the Sector Principle and the other Arctic States considered it, whereby national boundaries that are unobstructed by other sovereign states to the north are extended parallel to longitude all the way to the North Pole, creating a wedgeshaped claim culminating at the Pole as a point, dividing the earth like sections of a peeled orange. Canada made the first claim in 1925, claiming the Arctic Ocean to the North Pole between $60^{\circ} \mathrm{W}$ and $141^{\circ} \mathrm{W}$ longitude. ${ }^{3}$ The Soviet Union followed in 1926 by claiming the arc of longitude between $35^{\circ} \mathrm{E}$ and $170^{\circ} \mathrm{W}$ longitude. ${ }^{4}$ Norway (claiming $5^{\circ} \mathrm{E}$ to $35^{\circ} \mathrm{E}$ longitude) and the United States (claiming $170^{\circ} \mathrm{W}$ to $141^{\circ} \mathrm{W}$ longitude) both quickly followed. ${ }^{5}$

Currently, the primary economic driver of interest in the Arctic is oil and gas reserves. Some estimates of the hydrocarbon potential of the Arctic place 20.0 percent of the world's undiscovered reserves within the confines of the Arctic Ocean. ${ }^{6}$ Fishing rights and rights to shipping are other concerns. Looming in the background are political and military concerns - Russia and the Canada/United States axis have a long history of military tension and terse diplomacy in the Arctic and elsewhere.

\section{International Legal Regime of the Arctic}

Territorial disputes continue all around the Arctic Ocean. Under international law, no country currently has an internationally recognized claim to the North Pole or the region of the Arctic Ocean immediately surrounding it because these environs are not

3 T. E. M. McKitterick, "The Validity of Territorial and Other Claims in Polar Regions," Journal of Comparative Legislation and International Law, 3rd Ser., XXI, 1 (1939), 89-97.

4 Ibid.

5 Ibid.

6 Kenneth J. Bird et al., "Circum-Arctic Resource Appraisal: Estimates of Undiscovered Oil and Gas North of the Arctic Circle," U.S. Geological Survey Digital Data Series — DDS60. 
located on the continental shelf, but rather over the abyssal plain of the Arctic Ocean, hundreds of miles from the shore. The contentious point, however, are the sea ridges which extend from Eurasia and North America.

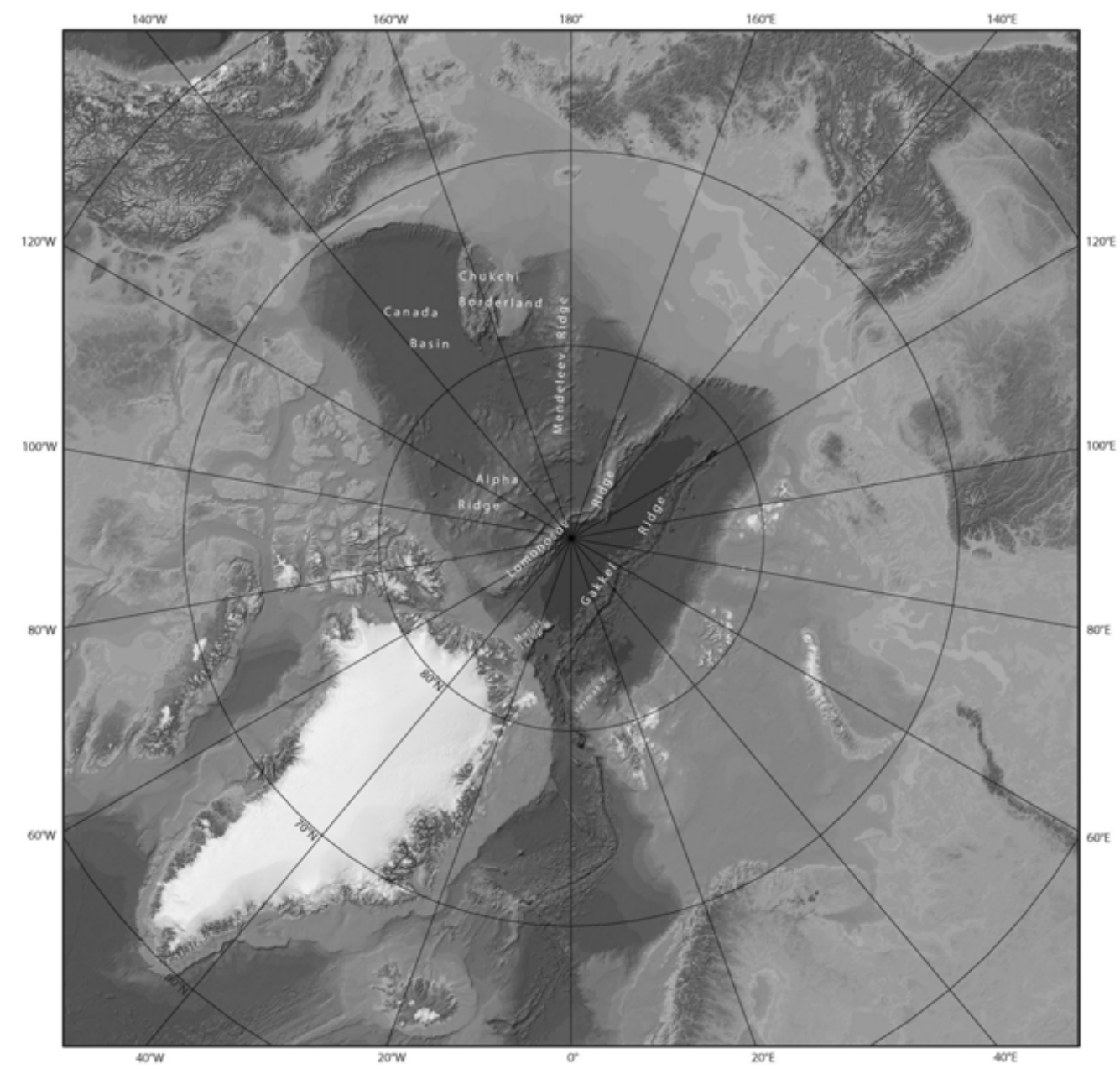

Bathymetric and topographic tints

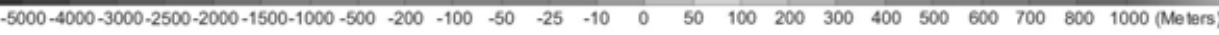

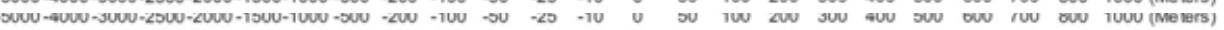

Figure 1: Topographic/bathymetric Map of the Arctic Ocean and it environs. Russia has made claims that the sea ridges extending from Asia serve to extend its territorial waters. Other countries, led by Canada, dispute this. (Source: National Geophysical Data Center, NOAA, http://www.ngdc.noaa.gov/mgg/bathymetry/arctic/maps/IBCAO_ver2_23_Letter.pdf)

After World War II, Sector Principle-based claims were dropped in favor of claims based on the Exclusive Economic Zone ("EEZ"), a boundary of 200 nautical miles from the coast first described in the UN's third Conference on the Law of the Sea (hereafter, all conferences collectively being the Convention referred to as "UNCLOS"). 
The continental shelf is a portion of a continent which extends from the shoreline and slopes gently out to the continental break, and can be wider than 500 miles in places. At the continental break, the slope deepens suddenly, plunging to the abyssal plain. International law recognizes that such portions of continental crust are essentially parts of the continent, just under a thin ( $>200$ meters) layer of water. Modern technological progress makes production of seabed resources feasible at these depths.

While "international waters" were traditionally the oceans away from the sight of land during the age of sailing ships, the advent of air power, better maps, and faster ships have all contributed to pushing the accepted nautical boundaries of national influence further seaward. Recognizing this, the United Nations was the forum that modern countries used as a platform to discuss and shape international maritime law.

The 1958 UN Convention on the Continental Shelf was one of the conventions promulgated at the UN's 1956 Conference on the Law of the Sea. Entered into force on 10 June 1964, the Convention on the Continental Shelf established the rights of a sovereign state over the continental shelf that may be adjacent to it. It joined the Convention on the Territorial Sea and Continuous Zone, the Convention on the High Seas, and the Convention on Fishing and Conservation of Living Resources of the High Seas as the four parts of UNCLOS I.

UNCLOS became effective on 16 November 1994, and is currently applicable to 157 countries and the European Union.

\begin{tabular}{|l|l|}
\hline Country & Status and Date of Ratification \\
\hline Canada & 3 November 2003 \\
\hline Denmark (Greenland) & 16 November 2004 \\
\hline Finland & 21 June 1996 \\
\hline Iceland & 21 June 1995 \\
\hline Norway & 24 June 1996 \\
\hline Russia & 12 March 1997 \\
\hline Sweden & 25 June 1996 \\
\hline United Kingdom & 25 July 1997 \\
\hline United States & (not yet ratified) \\
\hline
\end{tabular}

Table 1: Countries proximal to the Arctic and their date of ratification of UNCLOS - the United Nations Convention on the Law of the Sea.

Claims beyond the EEZ can be made in special cases. In the Arctic, one source of these claims by countries for sea sovereignty past the EEZ and into the "International High Seas" zones - those areas of the Arctic Ocean and vicinity that are further from the shoreline than any existing or projected EEZ limit (see figure 1) - are the sea ridges which run across the seafloor and rise above the abyssal plain. The Arctic Ocean Commons abyssal plain consists of flat oceanic sedimentary basins partitioned by these volcanic ridges. The question of whether these sea ridges will become treaty-recognized geological extensions of the continental shelves of one or more of the surrounding five 
countries — and thus possibly an sovereign extension of the shelf — or if they will remain in international waters has grown into a complex and divisive international issue.

Continental shelf extension claims beyond the internationally recognized limits are resolved primarily by analysis and interpretation of geomorphological and bathymetric data. $^{7}$ In 1996, experts from the five coastal states that border the Arctic Ocean - Canada, Denmark (via Greenland), Norway, Russia and the United States gathered to discuss their respective continental shelf claims beyond 200 nautical miles in the Arctic Ocean. All the participants agreed that all five countries had valid grounds for developing continental shelf claims beyond the minimum EEZ limits and that some of these claims may overlap.

The EEZ extends from islands as well, sometimes greatly extending the EEZ from the shoreline of the continent, a phenomenon seen in the Canadian, Norwegian and Russian EEZs of the Arctic Ocean. This is another source of dispute. For example, based upon geomorphological and bathymetric evidence supplied by Norway in 2006, the UN Commission for the Limits of the Continental Shelf (the "CLCS") approved Norway's claim to the vast chunks of seabed in the Norwegian Sea, the Barents Sea and the Arctic Ocean. The CLCS also found, however, that Russia and Norway both had a legitimate claim to one portion of the Barents Sea that is very prospective for hydrocarbons, and decided it was up to the two countries to find a joint participation protocol between them. ${ }^{8}$

\section{Bi-Lateral and National Legal Regimes of the Arctic and Domestic Policies}

The UN is not the only organization that monitors the region. More specific to the region is the Arctic Council. This intergovernmental organization is comprised of eight states: Canada, Denmark, Finland, Iceland, Norway, Russia, Sweden and the United States, as well as several associations representing aboriginal groups in the Arctic. ${ }^{9}$ It is intended to provide a high-level forum to address the common regional questions and concerns faced by the Arctic governments and people of the Arctic. The Arctic Council is presided over by a rotating Chair nation, a position currently shared by Denmark and Sweden. The Arctic Council's primary areas of concern are the environment and climate change, such as promotion of the Arctic climate Impact Assessment, and conservation and sustainable development of economic Arctic fauna and flora such as reindeer and fish.

Some groups have promoted the idea of an "Arctic Treaty" which is envisioned to be a counterpart to the Antarctic Treaty. ${ }^{10}$ Such a treaty would not recognize territorial sovereignty claims, would prohibit military activity and would likely preclude significant

$7 \quad$ Article 76 of UNCLOS.

8 Daniel Lauten, "UN Backs Norway Claim to Arctic Seabed Extension", Agence FrancePresse, 15 April 2009.

9 The Arctic Counsel maintains a website at http://www.arctic-council.org/ (last visited: 5 April 2009).

10 Donat Pharand, "Draft Arctic Treaty: An Arctic Region Council," Canadian Arctic Resources Committee, 1991, AI-A10. 
oil and gas exploration over any territory it covered in the Arctic. Who exactly would interpret and enforce an Arctic Treaty remains conceptual, but proponents have pressed for the formation of an Arctic Region Council which would carry out these duties. ${ }^{11}$

International bilateral treaties governing boundary divisions in the Arctic have a long history, far longer than the UN has been in existence. In 1825, Imperial Russia and a young United States ratified the Russo-American Treaty of 1824, wherein Russia gave up any claim to what is now Oregon and Washington. A similar treaty between England and Russia in 1825 defined the southern border of Russian Alaska and British Columbia. Once Alaska was purchased from Russia in 1867, America inherited a border dispute with the English authorities then ruling British North America, which lasted until arbitration finally settled the border in 1903.

National statements of sovereignty also have a long history in the Arctic. Outside of coastal water claims by the Arctic States, however, until the1990s the majority of the Arctic Ocean, including the North Pole, had been generally considered international high seas. However, since the polar icecap has begun to recede, several countries have made moves to claim, or to enforce pre-existing claims to, the waters or seabed of the Arctic Ocean.

\section{Canada}

Canada's claim to the Arctic comes from its continental exposure in the northern portions of the Yukon and Northwest Territories and Nunavut. Canada and the United States currently dispute the sovereignty of a wedge-shaped slice of seafloor located within the Arctic Circle under the Beaufort Sea in the area north of the intersection of the Arctic Ocean shoreline. The wedge borders the State of Alaska and the Yukon Territory of Canada. The Canadian position is that the maritime boundary should follow the land boundary. The disputed area may hold significant hydrocarbon reserves. Canada has protested diplomatically in response to American oil and gas leasing in the disputed land.

A quarter century after claiming an arc of longitude all the way to North Pole, Canada relocated some Inuit people — Canadian citizens - to previously uninhabited islands in what is now the Territory of Nunavut. The motivation for this small relocation has been attributed by some to "the desire by Canada to assert its sovereignty over the Arctic Islands and surrounding area." 12

Canada also claims all the waters between the Canadian Arctic Archipelago as its own internal waters. Thus, ownership of a section of the Northwest Passage is disputed as Canada considers it fully under Canadian jurisdiction. This view is not shared by most other counties. Another complication centers upon Canada's argument that all interarchipelago are "archipelagic waters" under the UNCLOS. In 1970, the Canadian

11 United Nations Environment Program Global State of the Environment Report, 1997. An electronic copy is maintained at http://www-cger.nies.go.jp/geo1/ch/ch3_31.htm (last visited: 12 April 2008)

12 Frank J. Tester, Tammarniit (Mistakes): Inuit relocation in the eastern arctic 1939-63 (Vancouver, 1994), 113-118. 
government enacted the Arctic Waters Pollution Prevention Act (AWPPA). This act asserted Canadian regulatory control over pollution within a 100-mile distance from shore - which would include the straits of the Northwest Passage.

In contrast, the United States and most maritime nations consider all of the Northwest Passage to be an international strait, which means that foreign vessels have right of "transit passage" and thus Canada would be precluded by international law from closing the passage. The Americans flatly rejected the AWPPA and responded to the Canadian claims of sovereignty by driving the reinforced oil tanker Manhattan through the Northwest Passage in 1969, followed by the icebreaker Polar Sea in 1985, both without asking for Canadian permission.

A stopgap truce was reached in January 1988, three years after the passage of the Polar Sea, by bilateral pledges that voyages of American icebreakers "will be undertaken with the consent of the Government of Canada." However the agreement did not alter either country's basic diplomatic position. As recently as late 2007, President George W. Bush and Prime Minister Stephen Harper again publicly took opposite positions regarding the Northwest Passage. With the retreat of sea ice in the Arctic and the corresponding increase in Arctic shipping, the importance of the outcome of this conflict will wax with time.

In December 1996, Canada enacted Canada's Oceans Act, which, among other purposes, affirms in Canadian domestic law Canada's sovereign rights, jurisdiction, and responsibilities in the exclusive economic zone of Canada. The Oceans Act exerts Canadian claims to the Arctic in three ways. First, under Section 7 of the act, Canada claims a 12-mile territorial Arctic sea as part of Canada. Second, under Section 13 of the act, Canada establishes a 200-mile EEZ around an Arctic Archipelago. Third, under Section 17 of the act, Canada claims rights to a portion of its continental shelf that extends into the Arctic Ocean and provides for later claiming an even further continental shelf.

In addition to making claims to the Arctic through domestic law, the Canadian government also became a party to UNCLOS. The Canadian government followed its ratification of UNCLOS with funding, allocating $\$ 69$ million to conduct seabed surveying and mapping.

\section{Greenland (Denmark)}

Denmark bases its jurisdiction to the Arctic on Greenland's coastline. Greenland is an autonomous province of Denmark, which covers a longitudinal arc from $60^{\circ} \mathrm{W}$ to $10^{\circ} \mathrm{W}$. Denmark's sovereignty over all of Greenland was recognized by the United States in 1916, a claim further enhanced by an international court in 1933. Greenland has since become a Danish autonomous province. Greenland has the nearest coastline to the North Pole, and Denmark argues that the Lomonosov Ridge is in fact an extension of Greenland. To promote their presence, the Danes have recently participated in a number of scientific expeditions in the Arctic, including 2007-2008 International Polar Year program, working with ships from the Swedish and Russia. 
Additional research included a 2007 joint expedition by Russian and Danish icebreaker ships that conducted seafloor mapping of the Lomonosov Ridge. Though Russia and Norway are the only countries that have currently made an official submission to the UN regarding their Arctic Circle claims, it is likely that Denmark, based on its rapid movement since ratifying the UNCLOS, will be the next country to figuratively plant its flag in the Arctic Circle.

In another surprising snit between generally peaceful countries, Denmark and Canada are at odds over Han Island, a small and uninhabited island between Greenland and Ellesmere Island, Canada, in the Nares Strait. Denmark has repeatedly placed flags on Han Island over the last two decades. In response, the Canadian Defense Minister made a surprise visit to the island in the summer of 2005, asserting Canadian sovereignty.

Of all the countries encircling the Arctic, Denmark/Greenland is unique because of the relationship between the mother country, Denmark, and the semi-sovereign Greenland. Denmark granted Greenland home rule status in 1979, and on 21 June 2009, Greenland overwhelmingly passed a self-government referendum establishing independent control of Greenland's courts and coastguard.

\section{Iceland}

While Greenland interrupts Iceland's approaches to the Arctic Ocean, Iceland's location in the north-central Atlantic is the basis for its claim under UNCLOS to a large portion of the Atlantic between Greenland, Norway and the United Kingdom (see Figure 1). Despite its small size and population, Iceland has not shied away from conflicting claims with other countries over sea rights, starting with the "Cod wars" of the 1950s and 1970s between the UK and Iceland regarding fishing rights in the North Atlantic and continuing today with disputes with the UK, Ireland and Denmark over Rockall.

Rockall, a small, uninhabited, rocky islet in the North Atlantic Ocean whose ownership is disputed, is the focus of a conflict between the UK, Ireland, Denmark, and Iceland. Iceland does not claim the rock itself, considering it irrelevant as far as delineation of its EEZ and continental shelf is concerned, but does claim an extended continental shelf in the Hatton-Rockall area. Specifically, Iceland claims the area within sixty nautical miles from the foot of the continental shelf and assumes that the UK and Ireland can not claim a continental shelf outside their EEZs.

In 1985, in addition to becoming the first Western county to ratify UNCLOS, Iceland also outlined the extent of Iceland claims to the continental shelf, seeking the exclusive right to research and exploit resources within the limits of the Icelandic continental shelf. Sixteen years later, in 2001, Iceland began working on its formal submission to the Commission. Although an area thirteen times larger than the land area of Iceland was surveyed by Icelandic marine research institutions in conjunction with this claim.

\section{Russia}

With increased polar exploration came sovereign claims to Arctic islands. In its 
last days, the Imperial Russian court claimed certain islands off the shore of Siberia, including Bennet, Jeannette, Vil'kitskii, Severnia Zemlia and Herald islands. Spurned by continuing exploration to its north, and perhaps sensitized by the perceived weakness of the new government after the October Revolution and its drawn out aftermath, the Soviet government was quick to take up again the Russia claim to Arctic islands off the coast of Siberia. In the USSR's TsIK Presidium of April 15, 1926, it was decreed that all lands and islands north from the USSR coastline up to the North Pole between $32^{\circ} 04^{\prime} 35^{\prime \prime} \mathrm{E}$ and $168^{\circ} 49^{\prime} 30^{\prime}$ West (except for Spitzbergen) were the territory of Soviet Russia. Currently, the Russian Federation upholds this claim.

In December of 1991, the Russian Federation was the first to make a submission to the secretary-general of the United Nations for the Commission, pursuant to article 76, paragraph 8, of the UNCLOS. Russia has based its claim to the Arctic by arguing that the seabed below the North Pole is part of the Eurasian continental shelf, an area called the Lomonosov Ridge. ${ }^{13}$ In 2001, the Commission listened to Russia's argument that the ridge is an extension of its continental territory but decided that more evidence is needed before the Commission will agree to the Russian Federation's control of the area. ${ }^{14}$ In the meantime, Russian scientists have been gathering documentary scientific evidence, as Russia must file a claim under UNCLOS by the end of 2009 demonstrating that its continental shelf extends far beyond the 322 nautical kilometer zone to encompass most of the Arctic Circle. ${ }^{15}$

In 2007, Russia sent two mini-submarines on a mission to map the Lomonosov Ridge and take soil core samples in an effort to provide that the ridge under the Arctic is part of Russia's continental shelf. ${ }^{16}$ During the mission, a Russian submersible dropped a Russian flag onto the Arctic seabed below the North Pole. ${ }^{17}$ In an understated response to claims that the flag dropping symbolized Russia's claim to the Arctic, Russia's Foreign Minister Sergei Lavrov compared the incident to Neil Armstrong placing the U.S. flag on the moon. ${ }^{18}$ On his way to a meeting of the Arctic Nations in Ilulissat, Greenland on 27 May 2009, Minister Lavrov said that the flag was not a claim for territory, adding that "there couldn't be [such a claim] because there is the Law of the Sea Convention and there are mechanisms created to implement this convention." 19

13 Marsha Walton, "Countries in tug-of-war over Arctic resources," available at http://www.cnn.com/2009/TECH/science/01/02/arctic.rights.dispute/index.html, 2 January 2009.

14 Ibid.

15 Richard Lourie, "The Battle for the Great Bear," Moscow Times, Issue 4081, 9 February 2009.

16 Ria Novesti, "Medvedev: Arctic Resources are Key to Russia's Future," Seattle Times News available at http://seattletimes.nwsource.com/html/nationworld/2008187217_russia18.html (accessed 18 September 2008).

17 Vincent Lauerman, "Arctic that heats up seabed claims race; Canada among nations scrambling for status," Calgary Herald, 19 February 2009.

18 Ibid.

19 Ibid. 
According to the head of Russia's Security Council, Nikolai Patrushev, Russia claims eighteen percent of the Arctic region, which touches on 12,000 miles of the country's border. ${ }^{20}$ Russia has been open with its intention to make its portion of the Arctic a strategic resource base in the twenty-first century. For example, the Russian energy company Gazprom is counting on remote Arctic and offshore locations to provide half of its natural-gas production by 2020 as output declines sharply at mature Siberian fields. $^{21}$

Russia is prepared to vigorously defend its interests in the Arctic. ${ }^{22}$ Earlier this year, Russia announced that it is monitoring Arctic militarization by other countries more closely than in the past. ${ }^{23}$ In 2004, Russia created an Arctic directorate and established border guard stations in the area. ${ }^{24}$ In January of 2009, in response to NATO's call for military presence in the Arctic, Russia's Security Council said that "military force is not out of the question" in resolution of the problems in the Arctic. ${ }^{25}$

Russian newspapers have reported that Russian air and naval power in the region have become more visible as long-range strategic bombers fly over the Arctic, frequently shadowed by NATO aircraft, and Russia's Northern fleet based in Murmansk has expanded patrols. ${ }^{26}$ Last year, in an interview with Krasnaya Zvezda (Russia's military newspaper), General Vladimir Shamanov stated that the military is ready to fight any country that disputes Russia's rights to the continental shelf. ${ }^{27}$

\section{Norway}

One-third of mainland Norway and its coastline lie inside the Arctic Circle thereby providing Norway a basis for its claim to portions of the Arctic. Norway is already exploiting gas reserves in the Arctic as the Norwegian firm StatoilHydro ASA pumps natural gas from the Snøhvit field in the Barents Sea, condenses it into liquid and exports it to Europe and the U.S. Before the project, no one had ever produced liquefied natural gas in the Arctic.

Norway's gateway to the North Pole runs through Svalbard, a group of islands in the Arctic Ocean. Norway's sovereignty over the islands was established by the Spitzbergen Treaty, signed on 9 February 1920, and which recognized the full and (near) complete sovereignty of Norway over Svalbard (formerly Spitsbergen Archipelago). The

$20 \quad$ See note 16.

21 Ibid.

22 Ibid.

23 Reuters, "Russia Keeps Eye on Arctic," The St. Petersburg Times, Issue 1451(13), 24 February 2009.

24 Richard Lourie, "The Battle for the Great Bear," Moscow Times, Issue 4081, 9 February 2009.

25 Ibid.

26 Ibid.

27 Yulia Latynina, "Igor Sechin: The Great Arctic Conqueror," The St. Petersburg Times, Issue 1393 (57), 25 July 2008. 
exercise of Norwegian sovereignty is, however, subject to certain qualifications, and some non-Norwegian law applies regarding taxation, the environment and military activity. For example, the treaty allows all signatories to engage in certain commercial activities in the Svalbard, such as coal mining, of which both Norway and Russia currently partake.

Conflict exists, however, between Russia and Norway over Svalbard and the meaning of portions of the Spitsbergen Treaty. Norway believes that the treaty's tenets of equal economic access to the islands only apply to the actual islands themselves and their immediate territorial waters, but not to the wider EEZ. The Norwegian government also argues that the continental shelf around the Svalbard is part of mainland Norway's continental shelf, and should be governed by the 1958 Continental Shelf Convention. Russia argues, however, that the Spitsbergen Treaty's provisions of equal economic access apply to the entire 200-mile EEZ halo around the Svalbard. Finland publicly agrees with Norway; no other countries have expressed an official position.

Realizing the immense importance of its offshore gas reserves, Norway made an official submission to the Commission on 26 November 2006, regarding its claims to the Arctic Circle. In its submission, Norway argues that its 200 nautical mile continental shelf boundary should be extended into the Western Nansen Basin in the Arctic Ocean. The submission also states that an additional submission for extension of the boundary may be posted later.

Three Arctic nations - Denmark, Iceland, and Russia - filed responses to Norway's submission to the UN. Denmark and Iceland stated they had no objection to Norway's claim; Russia filed an objection, stating that a portion of Norway's claim overlaps Russia's claim to the Arctic. Though small in size compared to such Arctic countries as Russia and Canada, Norway — the world's third largest oil exporter — will likely continue to press hard for expanding its rights to the Arctic Circle and the many resources it contains.

\section{United States}

The United States bases its claim to the Arctic Circle through Alaska. Added as a territorial purchase from Imperial Russia in 1867, and partially invaded by Imperial Japan in 1942, Alaska joined the Union in 1959 as the forty-ninth state. However, nationalistic politicians in Russia have occasionally disputed American hegemony west of Canada. ${ }^{28}$ Additionally, the United States and Canada are in an ongoing dispute over ownership of a wedge-shaped slice of seafloor located in the Arctic Circle between Canada's Yukon Territory and Alaska. The Americans believe that the maritime boundary should extend along a path equidistant from the coasts of the two nations and have leased portions of the disputed land for oil and gas development, prompting protests from Canada.

The US has long recognized the potential oil and gas reserves in the offshore Arctic region. America's largest field, Prudhoe Bay, is located just off the coast of the

28 See Kevin Fedarko, et al., "Hello, I Must Be Going," Time, 10 January 1994 (details the views of Russian politician Vladimir Zhirinovsky.) 
North Slope in the Beaufort Sea. In 2008, the U.S. Geological Survey National Oil and Gas Assessment team in Denver released figures suggesting that the Arctic may contain upwards of about ten percent of the world's undiscovered oil and around thirty percent of the world's undiscovered natural gas. Combined, this represents over twenty percent of all undeveloped but technically recoverable hydrocarbons, with more than eighty percent of these located in the Arctic Ocean.

The United States has signed, but not yet ratified the UNCLOS. President George W. Bush asked the United States Senate to ratify the UNCLOS in a 15 May 2007, Presidential Statement. On 31 October 2007, the Senate Foreign Relations Committee voted 17-4 to send the ratification vote to the full U.S. Senate. The UNCLOS has still not been ratified by the U.S., however, in her 13 January 2009 confirmation hearing, Secretary of State Hillary Clinton testified that she will make obtaining ratification of the treaty a priority.

Despite current nonratification of the treaty, the United States' policies indicate interest and involvement in the area. In August 2007, a United States Coast Guard icebreaker went to the Arctic Circle to map the sea floor off northern Alaska to determine the extent of the continental shelf. Additionally, there is a planned expansion of the U.S. fleet of icebreakers - though this expansion currently lacks funding. It is likely that U.S. involvement in the Arctic will continue to increase in the coming months and years - the Arctic Circle is becoming more accessible due to the melting of the polar ice cap and the U.S. has a strong interest in finding new domestic sources of oil and gas. Perhaps a reflection of this urgency, with just a week left office, President Bush issued a presidential directive stating American policy in the region and calling — again — for the Senate to ratify the UNCLOS.

Some groups in the United States, however, are against ratification, citing taxation and expropriation of energy resources under the UN's UNCLOS enforcement arm, the International Seabed Authority (ISA) based in Jamaica. Potential cheating under the terms of UNCLOS by countries seen as less inclined to heed treaty terms than the United States, and impediments to American military use of the Arctic Ocean for transportation and logistics, have also been cited as reasons for continued nonratification of UNCLOS.

\section{Conclusion}

The political history of Arctic claims seems to have had three very general, overlapping phases. During the exploration phase, Arctic nations were more inclined to plant flags and make unilateral declarations about their claims to the north. Once the finite boundaries of the Arctic became more well known and communications between countries improved, more bilateral negotiations and agreements followed. With the advent of worldwide diplomatic agencies such as the United Nations, a more consensusbased, international intercession has arisen alongside the unilateral claims and bilateral diplomacy of yore. Despite the continued jostling over the Arctic, the Arctic States continue to acknowledge the new era of consensus and internationalism, at least for the record. Most recently, at the inaugural Arctic Ocean Conference held in Ilulissat, 
Greenland, on 27-28 May 2008, representatives of the five Arctic States convened to discuss matters related to oil and gas exploration, environmental regulation, shipping routes, and maritime security and emergency response. Perhaps the most noteworthy result of the conference was the Ilulissat Declaration, wherein the Arctic States pledged not only their continued cooperation among themselves, but also reiterated their dedication to the existing framework of international law:

Notably, the law of the sea provides for important rights and obligations concerning the delineation of the outer limits of the continental shelf, the protection of the marine environment, including ice-covered areas, freedom of navigation, marine scientific research, and other uses of the sea. We remain committed to this legal framework.... [which] provides a solid foundation for responsible management by the five coastal states....We therefore see no need to develop a new comprehensive international legal regime to govern the Arctic Ocean... ${ }^{29}$

Whether such endorsements represent a real dedication or are instead glossy diplomatic lip-service remains to be seen. Given the quickening tempo of development in the Arctic, however, the answer may come sooner than most expect.

\section{Acknowledgements}

The authors wish to thank Kraig Grahmann and Pierre Grosdidier, Attorneys, Haynes and Boone, LLP, Alla Nowowiejski, Attorney, Houston, Texas, and Byron R. Kulander, Professor Emeritus (Geology), Wright State University, for their assistance with completion of this article.

29 Excerpt from Ilulissat Declaration, adopted at the Arctic Ocean Conference hosted by the Government of Denmark and attended by the representatives of the five coastal states bordering on the Arctic Ocean (Canada, Denmark, Norway, the Russian Federation and the United States of America) held at Ilulissat, Greenland, 27-29 May 2008. 


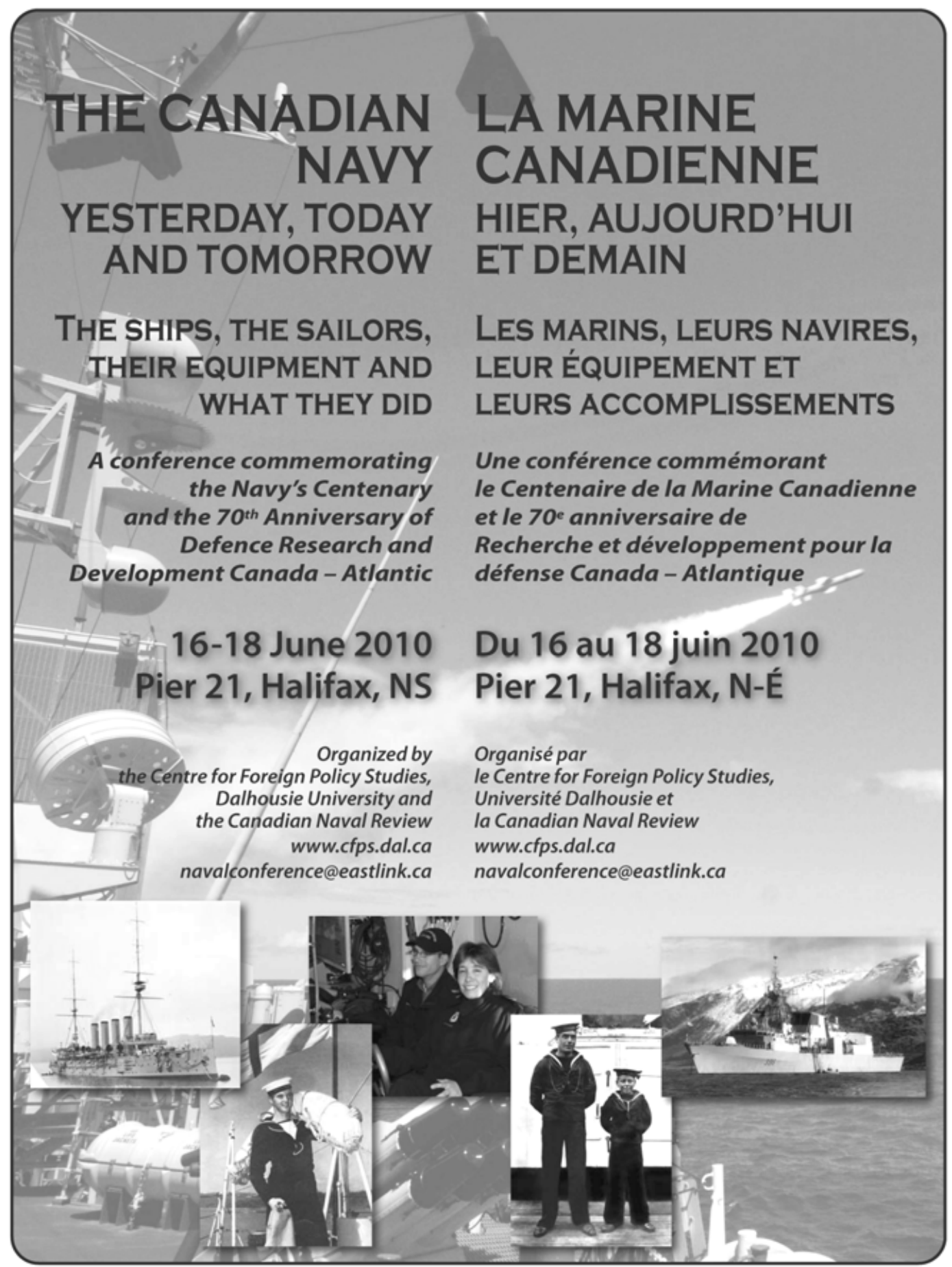

